\title{
Information and Analytical Support of Cost Control in Animal Feed Production
}

\author{
Zdorovets Iu.I.* \\ Belgorod state agricultural university named after \\ V. Gorin \\ Belgorod, Russia \\ e-mail: zdorovec1980@mail.ru \\ Kitaeva O.V. \\ Belgorod state agricultural university named after \\ V. Gorin \\ Belgorod, Russia \\ e-mail: Oksanauzhik@mail.ru
}

\author{
Kitaev Yu.A. \\ Belgorod state agricultural university named after \\ V. Gorin \\ Belgorod, Russia \\ e-mail: yurgenk@inbox.ru \\ Uzhik V.F. \\ Belgorod state agricultural university named after \\ V. Gorin \\ Belgorod, Russia \\ e-mail: Uzhik16@rambler.ru
}

\begin{abstract}
The subject of the study is the current approaches to the organization of cost management in agricultural enterprises. The purpose of the study is the formation of an integrated approach to building a cost management system in feed production taking into account the specifics of the enterprise. The article considers the key modern approaches to the formation of the cost control system and its information basis. As a result of the study, the main components of the concept of cost management for the production of animal forage at a closed-loop agricultural production enterprise were identified. The data presented indicate the need for an integrated approach to the information and analytical support of cost management, starting from the choice of the method of cost accounting, calculating the production cost, determining the target cost, and ending with the formation of management statements to analyze production efficiency. The paper presents the calculation of target cost indicators based on the target-costing and kaizen-costing systems and defines a list of the main forms of management statements of an agricultural enterprise.
\end{abstract}

Keywords - animal forage production, costs, cost control methods, prime cost, management statement.

\section{INTRODUCTION}

To make effective managerial decisions under the conditions of dynamic development of the market economy, an enterprise needs an appropriate information support system that objectively reflects the current economic situation. The transition to the market economy requires enterprises to increase production efficiency and competitiveness of products and services through the use of scientific and technological progress, effective forms of economic and production management, overcoming mismanagement, activating entrepreneurship, initiative, etc.

The important role in the implementation of this task is given to the analysis of the economic activity of enterprises. With its help, a strategy and tactics of an enterprise development are created, plans and management decisions are substantiated, their implementation is monitored, reserves for increasing production efficiency are identified, and the performance of the enterprise of its divisions and employees is evaluated.
Information support for production cost management is the relationship between the information and the enterprise management systems, and the management process as a whole. It can be considered not only as a whole, covering all management functions, but also for individual functional management work, for example, forecasting and planning, accounting and analysis. This makes it possible to shade off specific aspects inherent in the information support of functional management, revealing at the same time its general properties, which allows making the research more thorough. Under the current conditions, information support of cost management has become an important area, which consists in collecting and processing information necessary for making informed management decisions regarding the development of an enterprise aimed at increasing efficiency and profitability.

Particularly acute is the question of the optimal organization of cost management in animal forage production, which is spreading among agricultural enterprises that use a closed-loop production cycle.

\section{LITERATURE REVIEW}

Reserves for increasing profits, based on sales growth, are limited by the scale of demand in the market for both agricultural and processed products. In this regard, the emphasis in the profitability management is significantly shifted towards the production cost management, and these issues are of particular relevance. The basis for the development of a cost management system for an agricultural enterprise is cost accounting, since it is the basis for determining production prime cost, the basis for pricing, and determining the financial result of the production activities of the enterprise and ensures the competitiveness of products. To build the cost accounting system, not only modern approaches are currently used, but also their integration with foreign methods, which, in our opinion, is the most optimal option.

Traditional systems include a system of accounting for full and variable costs, accounting for standard costs, accounting at cost centers and responsibility centers. As for agricultural 
enterprises, they often use a full cost accounting system, as this approach is most habitual for practicing accountants. Some enterprises use the elements of the direct costing system to conduct a feasibility study and to make operational management decisions, which makes it possible to more objectively determine the production efficiency of a particular type of product based on a marginal approach. The use of the regulatory (standard) cost accounting is advisable in the case of applying cost control within the established norms and standards and for deviations from them. This approach can be used in processing plants, including feed mills. This is due to the fact that the main advantage of this system is the ability to quickly identify, and, therefore, eliminate negative trends in the process of control the cost and financial results of both an individual industry and an enterprise as a whole [4-6].

The use of a cost accounting system at cost centers or responsibility centers depends on the existing organizational structure of the enterprise. The place of cost occurrence is the organizational unit of the enterprise (team, department, site and workshop) that performs specific functions for which certain resources are required. The cost distribution is carried out in proportion to the selected distribution bases. The main disadvantage associated with the implementation of the cost accounting system for responsibility centers is its resource intensity [16]. Besides, the implementation of the system requires the establishment of integrated information systems, which leads to additional investment costs and increased qualification requirements for personnel to work in this information system $[14,15]$.

All the mentioned systems are closely interconnected and are often used together, forming a single accounting system of the enterprise. But at the same time, in our opinion, traditional systems have some drawbacks:

- traditional systems focus only on internal operations to account for production costs;

- there is a distortion of objective information on production costs, which entails the biased assessment of production;

- there is no analysis of external factors affecting the management decision making process.

Based on these drawbacks, it can be concluded that when using modern approaches to cost management in agricultural production, the disadvantages inherent in traditional approaches will be mitigated.

Currently, the effective management of the enterprise is based on a process-oriented approach. In this case, the term "process" can be interpreted as any action in an enterprise that can be both detailed and grouped. The process-oriented approach, in our opinion, is advisable to use in the management of enterprise costs. The process-oriented approach to cost accounting is based on the ABC (ActivityBased Costing) system, according to which the objects of accounting are actions from the process to the function. This system in its original form was used in the 1960s in the USA, and is currently used in various interpretations and is the basis for process-oriented management.
The disadvantages of existing cost accounting systems led to the search for new cost accounting options, one of which is the ABC (ActivityBasedCosting) system, which is widely used in Western companies in various industries. According to the $\mathrm{ABC}$ method, an enterprise is considered as a set of interrelated operations (functions) [10, 13]. During the operation, various resources are consumed (materials, labor, equipment). The type of activity refers to all the functions performed in order for the product to be provided to the buyer. Accordingly, the product assumes the costs of all types of activities that will be required for its creation and provision to the buyer.

The main disadvantages associated with the implementation and applications of the ABC method are its labor intensity, complexity, as well as significant financial and material costs for its introduction.

The JIT system is not an independent cost accounting system; it is a system for organizing production and the enterprise as a whole, which implies specific features of accounting and cost formation. The purpose of this system is to reduce unnecessary costs in the prime cost structure, reduce the cost of maintenance, storage, and transportation, efficient use of production facilities of the enterprise. The main advantages of the system are significant reduction in the cost of storage and transportation of stocks, which leads to the decrease in the share of indirect costs in the prime cost structure. However, some authors in their studies [11] emphasize that this system is mainly used in enterprises with a mass production.

BSC is a balanced scorecard, which is based on the management of key business processes assigned to the centers of responsibility of the organization in accordance with the organization's goals, quantitatively and qualitatively expressed in the target values of the estimated indicators in the context of four projections [2].

The key idea of a balanced scorecard is to shift the management's attention vector when evaluating a company's success from purely financial indicators. According to this concept, the enterprise management should monitor not only revenue and profits, but also other criteria related to customer relationships, improvement of internal business processes, etc. $[3,12]$.

The target-costing system is a management concept that supports a cost-cutting strategy and implements the functions of planning the manufacturing of new products, preventive cost control, and calculating target costs in accordance with market reality. Unlike traditional systems, it provides for the cost calculation for a product based on a pre-set selling price. This price is determined using marketing research, i.e. in fact, is the expected market price of a product or service. Target costing is also called goal pricing [7, 8, 17].

A natural continuation and an integral part of target costing is "kaizen costing", a system of continuous operational control over the cost level, small improvements, resulting in great results. At the same time, the both systems have the same task: achieving the target prime cost. However, this task is achieved in the first case (target costing) at the stage of designing a new 
product, in the second (kaizen costing) - at the production stage. The difference between the estimated and target prime cost should be minimized as much as possible at the product design stage, for which an analysis of drifting costs is carried out (analysis of the impact of each cost item on the prime cost of the product) and a search for the ways to reduce them. If it is impossible to obtain a given level of prime cost, the product is not launched $[1,9,18]$.

In our opinion, it is the advantages of the target-costing and kaizen -costing systems that allow the organization to successfully exist in the harsh competitive conditions.

Having considered the whole variety of cost accounting methods, it can be said that, based on the advantages and disadvantages of each of them, modern enterprises are able to achieve the goals of strategic management accounting, using either one of the management systems or a management model formed as a result of the integration of two or more methods. In this case, the choice should be reasonable. It should be noted that modern enterprises use a number of calculating tools, both traditional and advanced developments. Moreover, the traditional methods are currently the most common.

\section{METHODS AND MATERIALS}

Constantly changing operating conditions of agricultural producers lead to the need for constant monitoring of costs, production volumes, and the degree of their dependence on various factors. At the same time, based on the analysis of the available costs and their dynamics, the enterprise management needs to choose optimal approaches to the process of production cost control. In this case, it is necessary to take into account possible combinations of various methods of production cost control. The choice of one or another cost control method or their combination is determined by the specialization of the enterprise, the range of manufactured products, as well as the goal facing the heads of both structural divisions and the enterprise as a whole.

As an object of this study, an agricultural enterprise specializing in the production of pig breeding products was chosen, where the production of own forage plays a significant role in shaping the production cost in the core operation. The subject of the study was the current cost management system at the enterprise.

The abstract-logical, economic-statistical, and other research methods were used in the research process. We used data from the analytical cost accounting for the production of various types of animal forage, which are used both at the enterprise and sold on the other companies, as an information sources.

The research results can be used by agricultural enterprises involved in the production of animal feed for organizing cost management from the standpoint of improving their business efficiency and increasing profitability.

\section{RESULTS}

The current state of cost management in agricultural enterprises confirms the fact that most of them adhere to the traditional approach, which, in our opinion, is not exactly optimal. This conclusion is also based on the fact that often agricultural enterprises, in addition to crop production or animal husbandry, are involved in processing, for example, in the production of animal feed. In this case, the standard approach to organizing cost accounting and cost management is hardly the best available one. If we consider the setting up of a management system and cost accounting at feed mills or at enterprises that are engaged in the manufacturing this type of product for their own consumption, then the industry is characterized by the application of normative or process methods of cost accounting with preestablished standards for the consumption of raw materials, materials, and piece-hourly wages. But taking into consideration the current trends in the cost and profit management, it is advisable to use a process-oriented approach that will allow more objective assessment of the economic efficiency of the resource consumption and identify possible options for reducing cost overruns by cost items.

In order to determine the ways to increase the efficiency of resource consumption in the production of animal feed, it is advisable to analyze the structure of production costs. The production of animal feed is a rather material-intensive process, which is confirmed by the predominance of the material component in the cost structure, namely raw materials for processing. The level of production costs of animal feed is increasing annually due to growing prices for raw materials, electricity, rising tariffs for various services. The result of the resource consumption of the enterprise and the resulting effect on investments greatly depend on the choice of accounting and cost management procedure.

Considering the organization of cost accounting for the production of animal feed in one of the largest agricultural enterprises in the region, Agricultural Cooperative Society (ACS) "Kolkhoz named after Gorin", it can be noted that the process is based on the traditional approach, which involves the use of calculation by the absorption method. The algorithm of cost accounting in this case implies a complete accounting of production costs, including direct and indirect costs, which are distributed in proportion to the production volume. Production cost also includes general production expenses, while the overhead costs are covered by the financial result of the company. The choice of just such an approach to the prime cost formation for forage at the enterprise is also due to the fact that most of the feed produced is used to meet the needs of the pig industry, which is the key one in the ACS "Kolkhoz named after Gorin". Despite the fact that such cost accounting system is used at most enterprises, we would like to note its inherent disadvantages:

- due to enlarged cost groups and rather labor-intensive technological process, it is problematic to control the overrun of certain resources;

- lack of differentiation of indirect costs does not allow their detailed control and analysis;

- "conditional" approach to the distribution of general production expenses, the possibility of including in the prime cost of expenses that are not directly related to production;

- lack of control over the cost dynamics depending on changes in the dynamics of production volumes; 
- work in progress and finished goods inventories are valued based on the total cost, including indirect costs.

Given the fact that ACS "Kolkhoz named after Gorin" specializes in products of the pig breeding industry, produces crops used as raw materials for feed production at the enterprise, as well as due to the complex technological process, material consumption, and the duration of the operating cycle, the organization of the cost management system in general, and for the production of animal feed in particular, should be based on an integrated approach.

The entire process of managing feed production costs will include two main blocks. The first block "Production process of cost management" implies that for the formation of the production cost of feed, it is necessary to use the job-order method with elements of the standard-cost and direct-costing systems. The use of the job-order cost accounting method is based on the fact that the company produces compound feeds not only for its own needs, but by processing clients' raw materials. It is advisable to use the standard-cost system in the ACS "Kolkhoz named after Gorin" in terms of standardizing material costs based on the available formulas and labour costs. Non-production costs associated with the provision of various services by auxiliary industries, equipment maintenance, etc., should be rationally taken into account on the basis of the principles of the direct costing system, and be planned and controlled based on target indicators.

The second block "Production Cycle Management" of the cost management system in the ACS "Kolkhoz named after Gorin" should include elements of managing target profit and prime cost taking into account flexible budgeting. It is on the basis of information obtained in the framework of the first and second blocks that it is possible to carry out an objective assessment of the breakeven point of the production of animal feed at the enterprise and make an appropriate management decision.

In our opinion, when generating information on production costs at the ACS "Kolkhoz named after Gorin" for optimization of the cost management system, the following changes should be made.

1) information should be generated for each individual order to control the volume of production and sale of animal feed;

2) the enterprise uses standards for the resource consumption and write-offs of general shop expenses, therefore, to control the economy and cost overruns for individual costing items, it is necessary to use elements of the standard-cost system, which allows generating information taking into account the causes of deviations from the standards and the culprits of deviations;

3 ) to determine the breakeven point for the production of certain types of feed and the financial strength margin, information should be generated with the division of costs into fixed and variable (using the elements of the direct costing system);

4) to control the production cycle, it is advisable to use a combination of the kaizen-target system and flexible budgeting for the enterprise. The budgeting system allows the manager to assess in advance the effectiveness of managerial decisions, to optimally distribute the resources between departments, to outline ways of staff development to avoid a crisis. Based on the kaizen and target-costing, it is possible to develop cost estimates for individual departments and structural units. Together with the fixed cost budgets, the kaizen task can be used to formulate budgets for the upcoming fiscal year.

Thus, the cost management model of ACS "Kolkhoz named after Gorin" should be the interconnection of various accounting methods, both traditional, such as standard-cost, and modern kaizen -cost and target-costing. Only with the right combination of these systems, the enterprise will be able to achieve the main goal of any commercial enterprise which is to maximize profits, at minimal cost.

The authors consider in more detail the algorithm for the use of the Kaizen -costing and Target-costing systems, which are of particular relevance in our time. This is an innovative method that supports a cost-cutting strategy, so it is advisable to use it at agricultural enterprises. The concept of target costing is a holistic management concept that supports a cost reduction strategy and implements the functions of planning the production of new types of products (for example, types of animal feed), proactive cost control and calculating target costs in accordance with market reality.

To calculate the prime cost of products, the expenses for the production of animal feed are grouped and taken into account in terms of costing, which allows controlling the correctness and appropriateness of costs and find reserves to reduce the cost of production. At the initial stage, benchmarks are determined for the production process (Table 01).

TABLE I. KEY BENCHMARKS IN TERMS OF FEED TYPES*

\begin{tabular}{|l|l|l|l|}
\hline \multicolumn{1}{|c|}{ Indicators } & \multicolumn{1}{c|}{ PK-4 } & \multicolumn{1}{c|}{ PK-5 } & \multicolumn{1}{c|}{ PK-6 } \\
\hline Contemplated price per unit & 15650 RUR & 14250 RUR & 16850 RUR \\
\hline Target IRR & $20 \%$ & $20 \%$ & $20 \%$ \\
\hline $\begin{array}{l}\text { Possible annual production } \\
\text { volume }\end{array}$ & $10000 \mathrm{c}$ & $10000 \mathrm{c}$ & $10000 \mathrm{c}$ \\
\hline Estimated prime cost & $13146 \mathrm{RUR}$ & $12027 \mathrm{RUR}$ & $14424 \mathrm{RUR}$ \\
\hline Target prime cost & $12520 \mathrm{RUR}$ & $11400 \mathrm{RUR}$ & $13480 \mathrm{RUR}$ \\
\hline $\begin{array}{l}\text { Difference between estimated } \\
\text { and target cost }\end{array}$ & $\begin{array}{l}626 \mathrm{rubles}- \\
4.8 \%\end{array}$ & $\begin{array}{l}627 \mathrm{rubles}- \\
5.2 \%\end{array}$ & $\begin{array}{l}944 \mathrm{rubles}- \\
6.5 \%\end{array}$ \\
\hline
\end{tabular}

a. *calculated by the authors based on the data from ACS "Kolkhoz named after Gorin"

After determining the target cost in target costing method, the kaizen costing system is used. Reducing the difference between the estimated and target cost is called the Kaizen task, which applies to all personnel of the organization, from manufacturing workers to managers. The Kaizen task is determined at the planning stage for the next financial year, when production plans are developed. It is set both at the level of each type of feed, and at the level of the enterprise as a whole. To set the kaizen problem for the enterprise as a whole, one needs to know the percentage of planned annual profits, annual revenue, and the amount of variable (estimated) costs.

In the considered example the planned profit is $20 \%$, annual revenue is 21900000 rubles. So, the target cost will be 
17520000 rubles $(21900000$ rubles - 21900000 rubles $\mathrm{x}$ $20 \%)$. The difference between the estimated and target cost is 1360000 rubles (18 $880000-17520000)$, or $7.2 \%$. The Kaizen task for the enterprise of $7.2 \%$ means that in the production process in general the variable costs should be reduced by $7.2 \%$ (1 360000 rubles). For this purpose their individual Kaizen tasks are set for each variable cost item (Table 02).

TABLE II. VARIABLE COSTS FOR EACH ITEM CALCULATED PER THE PRODUCTION VOLUME (THS RUR)

\begin{tabular}{|l|l|l|l|l|}
\hline \multicolumn{1}{|c|}{ Cost item } & PK-4 & PK-5 & PK-6 & Total \\
\hline $\begin{array}{l}\text { Manufacturing workers' wages with } \\
\text { social security contributions }\end{array}$ & 170 & 2100 & 1600 & 3870 \\
\hline Grain and bean raw materials & 290 & 4300 & 3290 & 7880 \\
\hline Works and services & 110 & 1800 & 1010 & 2920 \\
\hline Fixed asset maintenance & 80 & 1020 & 820 & 1920 \\
\hline $\begin{array}{l}\text { Semi-variable costs for production } \\
\text { organization }\end{array}$ & 70 & 850 & 580 & 1500 \\
\hline Other costs & 30 & 420 & 340 & 790 \\
\hline Total b. * & 750 & 10490 & 7640 & 18880 \\
\hline
\end{tabular}

After this the estimated cost should be optimized based on the implementation of the Kaizen task and the target costs should be achieved summing up to 1314.04 thousand rubles (Table 03).

TABLE III. KAIZEN TASK SETTING IN TERMS OF VARIABLE COST ITEMS*

\begin{tabular}{|l|l|l|l|l|}
\hline \multicolumn{1}{|c|}{ Cost item } & $\begin{array}{c}\text { Estimate } \\
\text { value, } \\
\text { ths RUR }\end{array}$ & $\begin{array}{l}\text { Planned } \\
\text { reductio } \\
\text { n, ths } \\
\text { RUR }\end{array}$ & $\begin{array}{c}\text { Kaizen } \\
\text { task, \% }\end{array}$ & $\begin{array}{c}\text { Target } \\
\text { costs, } \\
\text { ths } \\
\text { RUR }\end{array}$ \\
\hline $\begin{array}{l}\text { Manufacturing workers' wages with } \\
\text { social security contributions }\end{array}$ & 3870 & 506 & 13.7 & 3364 \\
\hline Grain and bean raw materials & 7880 & - & - & 7880 \\
\hline Works and services & 2920 & 369 & 12.6 & 2551 \\
\hline Fixed asset maintenance & 1920 & 189 & 9.8 & 1731 \\
\hline $\begin{array}{l}\text { Semi-variable costs for production } \\
\text { organization }\end{array}$ & 1500 & 214 & 14.2 & 1286 \\
\hline Other costs & 790 & 82 & 10.3 & 708 \\
\hline Total & 18880 & 1360 & 7.2 & 17520 \\
\hline
\end{tabular}

c. * calculated by the authors based on the data from ACS "Kolkhoz named after Gorin"

The advantage of the target and kaizen costing systems is the cost reduction and ensuring the profitability of production with simultaneous and continuous process of optimizing all business activities. The disadvantage is the complexity of organizing the systems and great dependence on the human factor. However, the use of these systems is possible in almost any industry, including agribusiness organizations, when combined with other cost management methods.

Another element of the second cost management block is the mandatory information component - management statement. To characterize the level of production profitability (or loss), management statements may include data on planned and actual costs per ruble of products (work, services) for the enterprise as a whole, its structural divisions, types and segments of economic activity. The evaluation of the results of the production units of the enterprise requires the reflection in the management statement of detailed information about the costs of each unit for the production of individual orders, types of products (works, services) for cost items. In order to organize the preparation of management statement in the local regulations concerning its formation, it is necessary to clearly define the data sources for obtaining each reporting indicator. To fulfill these requirements, managers who are responsible for the production of animal feed at ACS "Kolkhoz named after Gorin" are recommended to fill out an information card reflecting the information needs of the structural units of the enterprise (Table 04).

TABLE IV. INFORMATION CARD FOR INTERNAL MANAGEMENT STATEMENT

\begin{tabular}{|l|l|l|}
\hline \multicolumn{1}{|c|}{$\begin{array}{c}\text { Structural units } \\
\text { (centers of } \\
\text { responsibility) }\end{array}$} & \multicolumn{1}{|c|}{$\begin{array}{c}\text { Frequency of } \\
\text { reporting }\end{array}$} & \multicolumn{1}{|c|}{ Key indicators } \\
\hline $\begin{array}{l}\text { Feed production } \\
\text { statement (by types) }\end{array}$ & monthly & $\begin{array}{l}\text { Finished products in natural } \\
\text { and monetary terms }\end{array}$ \\
\hline $\begin{array}{l}\text { Statement on the } \\
\text { expenses and prime } \\
\text { cost of the feed (by } \\
\text { types) }\end{array}$ & monthly & Actual prime cost \\
\hline $\begin{array}{l}\text { Sales statement (by } \\
\text { feed types and } \\
\text { market outlets) }\end{array}$ & monthly & $\begin{array}{l}\text { Revenue, breakeven point, } \\
\text { financial safety margin }\end{array}$ \\
\hline $\begin{array}{l}\text { Income and expense } \\
\text { statement (in general } \\
\text { and by units) }\end{array}$ & monthly & $\begin{array}{l}\text { Revenue, variable cost, } \\
\text { marginal revenue, profit }\end{array}$ \\
\hline $\begin{array}{l}\text { Management } \\
\text { statement of financial } \\
\text { results (by the centers } \\
\text { of responsibility) }\end{array}$ & monthly & $\begin{array}{l}\text { Marginal revenue, operating } \\
\text { income }\end{array}$ \\
\hline
\end{tabular}

For the effective functioning of the "Management Statement" element, in addition to the reporting forms themselves, the rules for their preparation, transfer, and processing, including the procedure, terms, and persons responsible for their preparation, must be designed and approved. To create the information base for ensuring the process of efficient cost management for the production of animal feed at the on-farm level, it is recommended to use the following forms of internal management statement: feed production statement by type, statement on the expenses and prime cost of the feed by type, sales statement, income and expense statement, management statement of financial results (report on the responsibility center). In this case, the head of the organization should appoint persons authorized to provide information on the forms of internal management statement.

\section{CONCLUSION}

Under the modern business conditions, the management decision-making process is based on different information, including data on the cost-effectiveness indicators of economic entities. This is especially true for the agricultural sector, since the cost data are used to develop a strategy aimed at achieving sustainable competitive advantages. Having considered various approaches to the organization of cost management, it is possible to determine the following areas of its formulation for enterprises engaged in the production of animal feed: 
- the unit of analytical accounting of production costs should choose not only the type of feed, but also the order in the case of processing of raw materials;

- to form the prime cost and to analyze the production efficiency from the standpoint of assessing financial strength in the complex, one should apply the elements of the standard-cost and direct-costing methods;

- to control the cost conditions, use cost control elements based on the target profit and target cost due to the closed production cycle at the enterprise and the impact of the cost of feed on the efficiency of pig breeding production;

- form management statement forms taking into account the possibility of a marginal analysis of the feed production efficiency.

\section{References}

[1] G.S. Armashova, "Lean production as a factor of competitiveness of a business entity", Proc. of the Voronezh State Univer. of Engineer. Technol., vol. 81, no. 2, pp. 336-340, 2019. Retrieved from: https://doi.org/10.20914/2310-1202-2019-2-336-340

[2] I.D. Denima, "Modern trends in management accounting development", Everyth. for an account., vol. 6, pp. 39-43, 2012.

[3] A.V. Zilberman, "Balanced scorecard: precise vector", Consultant, vol. 17, pp. 8-12, 2012.

[4] Ju.I. Zdorovets, "Methodological approaches to the prime cost calculation process for the dairy cattle breeding products", Econ. and entrepreneurship, vol. 4, no. 105, pp. 1080-1083, 2019.

[5] Ju.I. Zdorovets, O.V. Goncharenko, "Features of the management accounting organization trading companies", Competitiveness in the global world: econ., sci., technol., vol. 8-1, no. 20, pp. 178-181, 2016.
[6] O.I. Zolotareva, "Improving the management accounting", Innovat. in the agro-industr. complex: probl. and prosp., vol. 4, no. 20, pp. 73-81, 2018.

[7] L.A. Zumakova, "The key approaches to the creation of the strategic management accounting system”, Int. account., vol. 33, pp. 36-40, 2013.

[8] Ju.N. Katkov, "Target costing and kaizen costing in cost optimization and prime cost calculation for the agricultural products", Account. in agricult., vol. 8, pp. 5-13, 2012.

[9] L.V. Kislitsyna, S.A. Kapustina, "Financial equilibrium as the special capital condition in holding: abilities to achieve", Proc. of the Voronezh State Univer. of Engineer. Technol., vol. 81, no. 1, pp. 351-356, 2019. Retrieved from: https://doi.org/10.20914/2310-1202-2019-1-351-356

[10] E.I. Kostyukova, I.G. Deryabina, "The experience of introducing the $\mathrm{ABC}$ method into the accounting practice of agricultural organizations", Int. account., vol. 37, pp. 15-20, 2014.

[11] S.I. Krylov, "Balanced scorecard: creation process", Int. account., vol. 11, pp. 17-25, 2012.

[12] N.N. Kudryavtseva, Y.V. Pakhomova, Y.N. Duvanova, "The concept of management development management enterprise", Proc. of the Voronezh State Univer. of Engineer. Technol., vol. 81, no. 1, pp. 429-433, 2019. Retrieved from: https://doi.org/10.20914/2310-1202-2019-1-429-433

[13] A.H. Kurmaniva, "Conceptual acpproaches to the formation of management accounting systems in organizations", Int. account., vol. 28, pp. 34-41, 2013.

[14] P.M. Lebedeva, "Direct costing, marginal costing, variable costing?", Int. account., vol. 3, pp. 14-19, 2013.

[15] O.V. Pochekaeva, "ABC method for cost control”, Int. account., vol. 2, pp. 12-15, 2013.

[16] L.A. Reshetnyak, "Accounting and analytical support of the finished goods at the animal feed producing companies", Innovat. in the agroindustr. complex: probl. and prosp., vol. 4, no. 20, pp. 99-104, 2018.

[17] R.N. Sungatullina, V.V. Zagarskih, "International experience in management accounting organization", Int. account., vol. 12, pp. 17-26, 2012.

[18] E.A. Suprunova, "Management accounting institutions in Russia: possible prospects and the search of the ways for their realization", Int. account., vol. 43, pp. 29-35, 2014 